\title{
The Imperial German Navy, 1897 - 1918: Negotiating the nation
}

\author{
Jesse Bachmann* \\ The University of Victoria \\ bachmannjesse@gmail.com
}

\begin{abstract}
This article seeks to analyze the linkages between the Imperial German Navy and Germany's domestic sphere from the years 1897 to 1918. Prior scholarship has suggested that the expansion of the Imperial German Navy, beginning in 1897, was strongly caused by internal domestic factors. This article disagrees with this assertion, pointing out how international concerns were the main motivating factor. Nonetheless, the paper does accept the general premise that the navy played a strong role in Germany's domestic sphere. To this end, this article analyzes how, prior to World War One, the navy was built into a national symbol aimed at overcoming the German empire's regional particularities. This article then bridges a gap in existing scholarship by linking the pre-war symbolic importance of the navy to its experience during the war and the naval revolts that occurred in 1918. In particular, this article argues that the national idea codified in the navy prior to the war was then challenged by the navy's generally poor experience during the First World War. This contributed to the naval revolts of 1918 which caused a reevaluation of the German nation and toppled the empire.
\end{abstract}

Keywords: Imperial German navy; imperial Germany; German high seas fleet; nationalism; German nationalism; social imperialism thesis; World War One; German naval revolts; German naval mutiny; German revolution 1918-1919; Richard Stumpf

\section{INTRODUCTION}

$\mathrm{O}$ n December 6, 1897, German Foreign Minister Bernard von Bülow gave a speech to the Reichstag, advocating that Germany embark on a policy of weltpolitik in contrast to the europapolitik of the Bismarck years, and declaring that Germany deserved a "place in the sun" (Holmes, 2010, p. 34). The europapolitik pursued by Otto von Bismarck had been focused on avoiding wars and maintaining a favourable balance of power in Europe. As such, he avoided aggressive imperial expansion (Alexander, 2012, p. 164, 183). After Bismarck's dismissal, the German government began to pursue weltpolitik which was characterized by an aggressive foreign policy aimed at expanding Germany's power, prestige, and empire. A large navy would be a key part in accomplishing this (Holmes, 2010, p. 37). One year after Bülow gave his speech, the first German naval law was passed through the Reichstag, inaugurating a massive expansion of the German navy that would last until the start of World War One and was supposed to propel Germany onto the world stage. While weltpolitik and German dreams of a 'place in the sun' suggests that naval expansion was undertaken primarily with international considerations in mind, the primary focus of this article will be to investigate and analyze the relationship between Germany's naval expansion and its domestic sphere. In this regard, this article has two primary

*I would like to thank Dr. Helga Thorson for her advice and feedback. 
objectives: Firstly, to evaluate and respond to the social imperialism thesis, and secondly, to address a historiographical gap in the domestic role of the German navy.

The social imperialism thesis has been posited by a number of German historians (see Mommsen, 1990; Wehler, 1962; Berghahn, 1987). The thesis argues that the navy, and the aggressive foreign policy it facilitated, was intended as a means of garnering domestic support and in this manner, strengthening the largely conservative imperial government's position in relation to the growing Social Democratic Party (SPD). This article counters this assertion by highlighting the degree to which those in charge of naval expansion were responding to foreign factors. Moreover, by drawing on new scholarship, particularly that of historian Jan Rüger, this article argues that the German government conceptualized the domestic role of the navy in broader terms; instead of being a tool to counter the SPD, the government saw the navy as a medium through which it could articulate its vision of a German nation.

Building on this foundation, this article seeks to bridge a historiographical gap in research on the Imperial German navy. Rüger's work has made progress in the identification of the navy's role as an anchor point for German nationalism prior to World War One. Meanwhile, historians such as Daniel Horn (1969), Holger Herwig (1973, 1980), and Michael Epkenhans (2005) have documented the activities of the German Navy during the war. However, the navy's prewar usage as a national symbol, and its subsequent wartime experience have not been explicitly linked or analyzed in terms of one another - at least not in English language scholarship. Making this connection seems natural, in particular because the navy's wartime experience culminated in the naval revolts of 1918. The naval revolts of 1918 had the immense domestic consequence of triggering the revolution that overthrew the Kaiser and ended a certain manifestation of the German nation. Hence, the navy was tied to questions of German national identity both prior to and during World War One, giving it a perceivable domestic profile. By establishing and then exploring this linkage, this article broadens the understanding of Imperial German history and argues that the Imperial Navy was constructed as a symbol of German national identity prior to World War one, and then during the war acted as a channel for the continued reevaluation of what was meant by the nation in the German context.

\section{The Social Imperialism Thesis}

German historian Hans-Ulrich Wehler first developed the social imperialism thesis in 1962 in his book Bismarck und der Imperialismus in order to explain Germany's colonial policy under Bismarck (Eley, 1976, p. 265). Mommsen (1990) defines social imperialism as an attempt by the ruling elite to provide a distraction from domestic social tensions through an aggressive foreign policy, and in this manner preserve the status quo. In particular, the ruling elite were trying to halt the growth of the Social Democratic Party (SPD) which was pushing for social reform (1990, p. 77). Although initially applied to the Bismarckian empire, historians later applied the thesis to the Wilhelmine empire to explain weltpolitik and the accompanying massive naval expansion. For example, Berghahn argues that weltpolitik was undertaken "in order to preserve the socioeconomic status quo at home," citing a society full of tensions in which a new industrial working class sought political power against "those forces which resisted any such reform" (1987, p. 31, 32). Mommsen (1990) stated that while social imperialism has some shortcomings, it provides the best framework for explaining German imperialism prior to 1914 (p. 77). Mommsen's assertion seems questionable. While there was certainly a link between naval expansion and Germany's domestic sphere, it was not causal; the emphasis social imperialism places on domestic considerations as driving or behind German naval expansion are somewhat overstated. Rather, naval expansion was undertaken largely as a result of international considerations. The role that Admiral Alfred von 
Tirpitz played in the expansion of the German Navy illustrates this.

In 1897 Admiral Tirpitz was appointed State Secretary of the Naval Office in 1897, making him the most influential man behind naval expansion (Herwig, 1980, p. 32). In this position, he drafted and passed all five of the naval laws through the Reichstag between 1898 and 1912 that were responsible for expanding the navy. The concerns guiding Tirpitz were largely foreign and international in nature. Prior to becoming Secretary of the Naval Office, Tirpitz spent twelve months in command of the German East Asian Cruiser Squadron which strongly influenced his worldview (Bönker, 2013, p. 61). Part of his duties at this post included finding a suitable position in China where Germany could establish a naval base in order to safeguard and increase its economic interests there. In doing so he quickly became aware of the immense strength of the British and Russian empires in the Far East, especially in comparison to Germany (Bönker, 2013, p. 64-79). The Russians had constructed a Far Eastern battle fleet on par with the British Far Eastern fleet, and wherever he looked for a suitable naval base he encountered British interests on the ground (Bönker, 2013, p. 77, 79). Essentially, his time in the Far East gave Tirpitz a sense of scale for imperial competition and indicated that Germany would have to match this if it wished to remain a great power. Hence, Tirpitz's vision for the German navy was born out of a consideration of foreign rather than domestic concerns; Germany would have to expand its navy if it wished to remain competitive on the world stage and not be dwarfed by other powers. Consequently, the emphasis the social imperialism thesis places on domestic issues appears to have insufficient support.

In addition to being initiated by foreign factors, naval expansion was also sustained by it. As the German fleet grew in size following the first naval law in 1898, the British began to take notice. They responded by reorganizing their navy to have more ships in home waters, neutralizing the growing German fleet (Massie, 1991, p. 462, 463). For German naval expansion to amount to anything, it would have to take this larger British home fleet into account. Hence, the second naval law of 1900 doubled the number of battleships the navy would build from 19 to 38 and included provisions for a plethora of smaller ships (Herwig, 1980, p. 42). Likewise, when the British launched the battleship HMS Dreadnought in 1906, its big gun main armament rendered all prior battleship designs obsolete (Herwig, 1980, p. 56). Once again, to stay competitive and for continued naval expansion to have an effect Tirpitz would have to respond. Although the cost of building Dreadnought class battleships made them potentially prohibitively expensive (the cost of a pre-Dreadnought battleship was 25 million marks while Dreadnoughts had reached prices as high as 59 million marks by 1913), Tirpitz accepted the British challenge and by 1908 the first German Dreadnought class battleship, SMS Nassau, had been launched (Epkenhans, 2011, p. 76, 85). Thus, it is clear that international and not domestic considerations played a significant role in animating German naval expansion.

While brief, this discussion has illustrated that the social imperialism thesis places too much emphasis on domestic issues in Germany as the explanatory mechanism for naval expansion. As has been shown, international factors played the defining role. Consequently, the relationship between the navy and Germany's domestic sphere needs readressing. Doing so will determine the contours of the following discussion.

\section{Navy As National Symbol: 1898-1914}

While the causal relationship that the social imperialism thesis posits between naval expansion and domestic tensions is flawed, there was indeed an important relationship between the German navy and Germany's domestic context. The expansion of the navy prior to World War One involved much more than the construction of new ships or enlarged harbours. As the fleet grew in size, so 
did its domestic importance. The regular facets of naval expansion were accompanied by a slew of public relations initiatives. The naming of ships was done with great care and according to specific requirements, the launching of these ships then became immense public ceremonies, and the Flottenverein was created as a public organization to further drum up support. Common to all of these initiatives was the manner in which they cast the navy as a symbol of German national identity. The navy was also used as a means to highlight the Kaiser's leadership of Germany, and he was presented as synonymous with the German nation. As such, within Germany's domestic sphere, the navy functioned as a symbol around which German nationalism could be built.

In order to analyze the relationship between the Imperial Navy and German nationalism, a working definition of nationalism is necessary. Anderson, in his well known book Imagined Communities, defined a nation as "an imagined political community" that is "both inherently limited and sovereign" (1983, p. 6). Even in the smallest nation the members of a nation will never meet all the other members of their nation, hence the community has to be imagined. At the same time, the breadth of whom is imagined as being included in this community is limited; the nation is an exclusive club. Anderson also notes that, while the nation is conceptualized as having "deep, horizontal comradeship" between its members, inequality and exploitation can exist within it. Finally, the nation is sovereign in that it is the source of legitimate political action (Anderson, 1983, p. 7). Considering the nuclei around which nations coalesce renders Anderson's definition more concrete. Alter identifies shared language, history, culture, or a "common subordination to a given state power" as focal points $(1985$, p. 8). Hence, nationalism can be understood as the act of creating or enforcing an imagined community around certain focal points. Indeed, Alter states that in nationalism, the nation "is placed upon the highest pedestal; its value resides in its capacity as the sole binding agency of meaning and justification" (1985 p. 9). Looking at the role of the German navy in the domestic sphere, it is clear that it operated along these lines, establishing a community wherein the nation is given utmost value.

Recent scholarship by Jan Rüger (see, 2007) has begun to investigate how the navy was invested with national symbolism. One element he identifies as indicative is the developments in the naming practices for German warships. In 1903, Kaiser Wilhelm II issued a decree on the naming of warships. Prior to the decree, German cruisers had generally been named after classical goddesses or female protagonists of the Nibelungen; now they were to be named after German cities. Between 1903 and 1914, twenty-five cruisers were launched with city names (Rüger, 2007, p. 147). Similarly, battleships, the largest, most expensive, most complex, and most prestigious ships a navy could build at this point in history, were now to be named after states or provinces within the empire (2007, p. 147). The new naming convention was in direct response to the regions of the empire.

In 1903, Germany was scarcely more than thirty years old and many of the previously independent states that had been incorporated into the empire by Bismarck still maintained distinct identities. A number of these states - most importantly Bavaria, Baden, Württemberg, and Saxony - had sided with Austria against Prussia in the Austro-Prussian war only five years before unification in 1866 (Rüger, 2007, p. 141). That these four states all lay in the south established a north-south divide within the new empire. This was further heightened by religious differences as southern states were largely Catholic, while their new Emperor and most of the northern states were Protestant (Lerman, 2008, p. 22). Moreover, the constitution of 1871, which brought these states together into an empire, afforded them a fair degree of autonomy in determining education, social policy, economic policy, and their own legal systems and electoral laws (Confino, 1997, p. 14). For example, Prussia had a three-tier electoral system that was heavily biased towards keeping conservatives in power while Württemberg had a more liberal and democratic political system (1997, p. 14). On a symbolic level, rather than portraying the bust of the new German 
emperor Wilhelm I, coins used in Württemberg portrayed the bust of its own king, Karl Alexander I, who maintained his position as king of Württemberg following unification (1997, p. 21). The army of Württemberg was incorporated into the new Imperial army as a distinct unit: the XIII Württemberg army division. This division was manned only by soldiers from Württemberg, resulting in the preservation of a distinct identity from the rest of the imperial army $(1997,21)$. Similarly, the army of Bavaria remained entirely separate from the imperial army (Gordon, 1964, p. 224). Thus, while the Prussian military might have created the political boundaries of the German empire in 1871, a corresponding national identity to tie this territory together was not firmly established, being contested with regional identities instead. The potential symbolic value of the navy was a means to counteract this.

The navy was used as a way of tying the local to the national, and in this manner broadening the horizons of the imagined community people saw themselves as belonging to. The previously mentioned naming of ships after distinct regions reflects this. It is no surprise that a large number of the battleships built for the imperial navy were given names that connected them to south German states. Examples of this include SMS König Albert, named after King Albert of Saxony; SMS Prinzregent Luitpold, named after Prince Regent Luitpold of Bavaria; SMS Markgraf, named in honour of the royal family of Baden; SMS Bayern, named in honour of Bavaria; and SMS Baden, named in honour of Baden (Rüger, 2007, p. 147-150). The construction of these ships was undertaken for the defence of the empire, not for the individual states after which the ships were named. Nonetheless, when these naming practices are considered against the German empire's regional divides, it communicates that these states were a part of something greater: a unified German nation. Moreover, it gave the individual states a symbolic role to play in the defence of this empire; citizens of a state could imagine themselves taking part in the collective defence of Germany through 'their' ship.

This pattern of linking individual areas of the empire to the larger notion of defending the nation was further developed in ship launching ceremonies. Prior to Germany's naval expansion, ship launching ceremonies had been quiet, unremarkable affairs. However, after 1898, they evolved into grand imperial pageants (Rüger, 2007, p. 41). Massive numbers of sailors and officers would be ordered to assemble in full ceremonial dress and attend the launching ceremony (Rüger, 2007, p.38). At the launching of SMS Prinzregent Luitpold in 1912 and 1926, 623 officers and sailors were mobilized to take part in the festivities (Rüger 2007, p. 149). Dignitaries from the locale after which the ship was named would be invited to the launching ceremony where they would give speeches (Rüger, 2007, p. 148). The speeches themselves were always heavily proofread and edited by the navy's public relations office, Nachrictenbureau, to ensure they had the correct message. The end result was a ceremony that elevated the value of the nation while bringing together different regions under that nation. At the launching of the battleship SMS Nassau, it was declared: "The inhabitants of this land [Baden] will feel with joyful pride that one of the proudest ships of the imperial navy will in future carry the name of their home over the seas" (Rüger, 2007, p. 148). The ship would then be addressed in the informal second person singular pronoun ' $\mathrm{Du}$,' reflecting the horizontal notion of comradeship central to the idea of a nation, and be bestowed with a mission of defending the fatherland (Rüger, 2007, p.40). Hence, Rüger conclusively illustrates how the naming and launching practices of warships operated as a centre point around which the imagined community of the German nation could be established. Of course, the use of warships for such a purpose amounts to an implied rhetorical statement that legitimizes fighting and dying in the name of the nation. Not only did warships establish the imagined community of the nation, they elevated its value beyond that of all other possible identifiers.

One of the difficulties of using a navy as a national symbol is that only people living along the coast would be able to directly see or interact with it. The Flottenverein (Navy League), which 
was a public organization, played a key part in overcoming this limitation. It was founded in 1898 after the passage of the first naval law by the Kaiser, Admiral Tirpitz, and in conjunction with the Krupp industrial family whose factories would provide the majority of the guns and armour plating for the new fleet (Park, 2015, p. 144). The Flottenverein's mission statement was "to awaken, cultivate, and strengthen the interest of the German people for the importance and function of the fleet" (Park, 2015, p. 146). Crucially, the Flottenverein was supposed to reach across different party, confessional, social, or class divides, bringing the nation together behind the idea of a strong fleet (Park, 2015, p. 131). As such, the Flottenverein aimed to be a truly nationalist organization.

The Flottenverein undertook a number of activities in order to build national public awareness about the fleet. One striking example was when the Flottenverein convinced admiral Tirpitz to send a whole division of torpedo boats down the Rhine to the Rhineland, the Palatinate, and Baden (Loiperdinger, 2002, p. 307). This allowed citizens of these states who would have never otherwise seen the navy in action to do so, once again broadening the scope of the imagined community to which they belonged. The idea of being able to see ships in action led the Flottenverein to make use of film, which at this point was new technology. In this regard, the Flottenverein was quite innovative. Launching ceremonies, sailing maneuvers, and artillery practice were all filmed and then shown to audiences, impressing them with the size, majesty, and firepower of the ships (Loiperdinger, 2002, p. 307-312). Since the ships acted as national symbols, the emphasis placed on these attributes of the fleet confers them on the nation as well. Audience turnout for the Flottenverein's films was large; in 1903/1904, the films had a nationwide total of more than 1.3 million viewers (Loiperdinger, 2002, p. 311). Consequently, the Flottenverein's pioneering use of film showings acted as a medium for disseminating national symbols (warships) and for elevating the nation that these warships symbolized.

Finally, it is crucial to note that the national symbolism invested in the navy was geared towards a certain interpretation of the nation. This interpretation centred around the type of state structure by which the German nation would be ruled and was thus most concerned with emphasizing the figure of the Kaiser. Kaiser Wilhelm II, despite his shortcomings, was attuned to the regional differences of the Reich and wished to overcome them (Thomas, 1991, p. 156). This came in contrast to his grandfather, Kaiser Wilhelm I, who, although having unified Germany, saw himself as primarily the Prussian King rather than German Kaiser (1991, p. 156). Wilhelm II, conversely, wished to make the Kaiser synonymous with the idea of the German nation - essentially fusing state structure and nation into one (1991, p. 167-172). He was also eager to take the empire that his grandfather had created and turn it into a 'world empire,' bestowing the German nation with greatness by making it second to none of the other great powers (Epkenhans, 2004, p.16) . Wilhelm II used every means at his disposal to do this and the Navy was one such method. The launching of a ship was laden with references to the Kaiser. Before a dignitary could start a speech, he would have to thank the Kaiser for the honour. During the speech, the ships' mission was commonly defined as fighting for the emperor; the phrase "loyal to your emperor, loyal until death" became a common refrain (Rüger, 2007, p. 153). Moreover, in fleet reviews, the Kaiser would first sail in the imperial yacht along his anchored warships until he got to the flagship, which he would then board. Taking his position of command on the bridge of the flagship, he would then observe the hoisting of the Imperial banner after which the fleet would set sail to preform manoeuvers and exercises with the Kaiser at command (Rüger, 2007, p. 187). It is telling that Reichstag deputies were never the ones upon whom the symbolic emphasis fell. All of the interactions between the Kaiser and the navy were designed to show the Kaiser as the patron and leader of the German navy and, in this manner, place him at the head of the German nation.

By combining the concept of the nation with the figure of the Kaiser, the navy was effectively 
giving licence to the state structure that the Kaiser symbolized. Prior to German unification, the strength of the Prussian royal family was served by the Junkers, who were a powerful landed nobility. The Junkers dominated the Prussian army's officer corps as well as the state bureaucracy and played a key role in the strength of the Prussian state (Merriman, 2010, p. 661). With the unification of Germany in 1871, the Junkers maintained their dominance over the state structure and political power (Merriman, 2010, p. 667). Simultaneously, unification brought large industrial growth to the German empire that changed its social landscape. In 1882, about $42 \%$ of the empire's population were employed in agriculture. By 1907, it was heavy industry that accounted for $42 \%$ of people's employment and agriculture had declined to around 25\% (Fairburn, 2008, p. 69). The expansion of heavy industry resulted in urbanization and the growth of a large working class. Subsequently, the Junkers' continued dominance over the Empire's state structure appeared anachronistic as the Junkers' interests were largely agricultural. This translated into the entire imperial government assuming a largely conservative character. The antisocialist legislation passed in 1878, which would make the empire's socialist party illegal until 1890, reflects this (Fairburn, 2008 , p. 65). Fusing the empire's state structure with the concept of the German nation managed to diffuse this social tension enough to prevent serious unrest. It made obedience to the state and an acceptance of a certain level of social inequality coterminous with nationalism. Mark Hewiston writes that "to a large extent, Imperial Germany's political system was protected and preserved because it was closely associated with a popular fatherland" $(2008$, p. 45). The combination of the navy, the nation and the Kaiser into a symbolic trifecta was a key part in achieving this association and attests to the power of nationalism to overcome social inequalities.

While this facet of the government's symbolic usage of the navy reflects certain aspects of the the social imperialism thesis - particularly the notion that naval expansion was calculated as a move to weaken the SPD in order to protect the socioeconomic status quo - the key distinction remains that domestic tensions of any shape or form where not the casual factor behind naval expansion. Additionally, the Imperial government's desire to use the navy as an institution around which it could construct a German national identity is a goal much broader in scope than countering the SPD. Indeed, the government was responding just as much to the German Empire's young age and regional characteristics as it was to the growing strength of the SPD. Hence, this article disagrees with the notion that the expansion of the German navy was caused by domestic concerns as the social imperialism thesis suggests. Instead, it argues alongside others such as Jan Rüger and Martin Loiperdinger that in Germany's domestic sphere, the navy functioned as a focus point for German nationalism. Ship names were consciously chosen to bring regions that might otherwise maintain a separate identity into the larger community of the nation. The means by which naming practices were then built upon during ship launching ceremonies added to the national symbolism imbued within the navy. The characteristics of the nation were also carefully delineated, and all emphasis was on portraying the Kaiser as the leader of the nation. The activities of the Flottenverein further tied together the imagined community by giving people a more concrete way in which to experience the navy. Finally, all of these undertakings elevated the value of the nation, presenting it as strong, unified, and worth dying for, as the centre point around which people's political actions revolved.

\section{Navy, Nation, and War: National symbol pUt to the test}

While recent scholarship has begun to recognize the national-symbolic importance of the Imperial German Navy, it has only considered this in the period of 1897-1914. There has been minimal scholarship explicitly analyzing how the navy's national symbolism functioned during the First World War. Filling this gap, and in particular, linking the Navy's national-symbolic importance 
with the naval revolts at the end of the war, is the task this paper will now turn to.

If prior to the war the value of the nation was established as something worth fighting and dying for, this was put to the test with the outbreak of war in late summer 1914. By 1918, sailors in the navy revolted, which quickly grew into a revolution, resulting in the abdication of the Kaiser. A number of structural features of the navy's experience in the war are key to understanding why the revolts occurred. Firstly, the fleet saw little action, depriving it of the ability to be victorious in battle and redeeming the sacred value of the nation. Secondly, and as a consequence of the first point, the fleet spent the majority of its time in port which proved monotonous and dull for the sailors. Thirdly, the monotony of life in port was aggravated by marked quality of life differences between officers and sailors, in particular on the issue of rations inequalities. The result was that sailors were unable to affirm their role in the defence of the nation, while class antagonisms between them and the officers were heightened. Ironically then, the sailors had lost faith in the national idea that the navy was supposed to symbolize. It was in these conditions that the sailors revolted in 1918.

By 1914, despite Tirpitz's best efforts to build a battle fleet that could challenge the Royal Navy, Germany lacked the number of ships required to do so. At the start of the war, Britain possessed 25 capital ships (21 Dreadnoughts and 4 Battlecruisers) to 16 German capital ships (13 Dreadnoughts and 3 Battlecruisers) (Herwig, 1980, p. 144 - 145). At the battle of Jutland in 1916, the only major naval engagement of the war, Germany's numerical situation was even worse: The British had 37 capital ships to 21 German ones (Herwig, 1980, p. 178). Although the British actually suffered higher losses than the Germans in the battle, they were also far more able to absorb these losses. Indeed, Admiral Scheer, who had commanded the German fleet at Jutland, delivered a report to the Kaiser following the battle stating "there can be no doubt that even the most successful outcome of a fleet action in this war will not force England to make peace" (Herwig, 1980, p. 190). To Scheer, Britain's numerical advantage in surface units was too great to overcome, and the German navy began to consider alternate strategies such as unrestricted Uboat warfare (Herwig, 1980, p. 190 - 197). As such, the German surface fleet spent the majority of the war in port. The lack of any great victory or action did little to help morale. Had the surface fleet played a more active role in the war, this could have validated the sailors' role in defending the fatherland and reaffirmed the supreme value of the nation. Indeed, morale did temporarily improve in the aftermath of Jutland, reflecting the positive impact that engaging in battle could have on morale (Horn, 1969, p. 31). Even leaders of the revolt looking back in retrospect felt that had the fleet engaged in battle more often, the revolt would have never occurred (Horn, 1969, 31).

Life in port was itself uninspiring. In order to keep the men occupied, officers resorted to menial and often pointless tasks. Drills became a common method for filling time (Horn, 1969, p. 21). For long and arduous work like loading coal onto ships, German officers would simply bark orders at the men. In contrast, British officers would often try and make a game or competition out of such tasks in order to keep them engaging (Horn, 1969, p. 26). Richard Stumpf, a sailor on the battleship SMS Helgoland, wrote a diary recounting his experience on the ship during the war attesting to this. He recounts how the incessant drilling amounted to farce. At one point, the crew of his ship were made to spend a week prepping the ship for an inspection only to find out on Friday that the inspection was no longer going to happen (Stumpf, 1967, p.149-151). "We had gone through all this trouble for nothing," remarked Stumpf caustically (1967, p. 151). Later he states, "I would rather carry rocks all day long if I new it served some useful purpose" (p. 283). Overall, Stumpf's diary illustrates a growing frustration with the pointlessness of his service. Additionally, as the Uboat campaign expanded, the best officers, the ones whom the sailors liked and respected, were taken from the surface fleet and put on Uboats instead. Thus, the surface fleet ended up being commanded largely by second-rate officers who were uninspiring and held 
superior, apathetic attitudes towards the sailors (Herwig, 1980, p. 230). Further aggravating this was the fact that there was little chance for respite or relaxation. Although the ships spent most of their time in port, they were usually on three to six hour alert, meaning that the sailors were unable to take any leave and escape from their drudgery (Horn, 1969, p. 27). The constant state of readiness also stood in marked contrast to the lack of action. These sources of discontent all helped create an atmosphere that made mutiny or outright revolt a growing possibility, but nothing more so than the quality of the sailors' rations.

As the war went on, rations only got worse. In Germany in general, after four years of war, daily caloric intake had decreased from 3000 to 1400 calories (Epkenhans, 2005, p. 76). On the surface fleet, during periods when Germany's food shortage was at it its worst, rations got so bad that the stokers - the men with the most physically arduous jobs of feeding coal into the ships' furnaces - would collapse from exhaustion (Horn, 1969, p. 40). It is telling that the first major sign of discontent was a strike conducted by the sailors on SMS Prinzregent Luitpold in protest over the poor quality of their rations (Epkenhans, 2005, p. 74). However, for the sailors, the biggest issue with the rations was the discrepancies between theirs and the officers'. Naval regulations stipulated that sailors were entitled to 1.32 marks worth of food per day, whereas officers were entitled to 3.65 marks worth of food per day (Horn, 1969, p. 43). The battleships of the high seas fleet were large enough that officers would have their own separate kitchens and rations, establishing a sense of separateness (Horn, 1969, p. 43). That morale was much higher on submarines and torpedo boats, wherein men shared the same kitchens and rations with officers, attests to the divisive role separate kitchens had (Horn, 1969, p. 43). If the lack of action and monotony of port life diluted the sailors' sense of national purpose, the differences in rations heightened the sailors' sense of inequality, straining the bonds of comradeship that normally tie together different social groups within a nation. Hence, sailors began to turn towards other identifiers, in particular, class.

Similarly, the superior and arrogant attitude of most officers was largely a product of their desire to maintain their own class standing. The officer corps was divided into three different types: executive, engineering, and deck officers. The navy was anxious to ensure that no one from less desirable social circles managed to enter the executive officers but at the same time had to face the fact that as the navy grew, manning the ships with executive officers from its preferred social circle - the nobility - would be difficult (Herwig, 1973, p. 68-79). The navy used the cost of the education required to become an executive officer as a means of keeping out those who came from too low a social standing (Herwig, 1973, p. 55). Completing a successful career as an executive officer was often accompanied with being raised to the rank of nobility by the Kaiser, thus offering the opportunity for social improvement and providing an incentive to join (Herwig, 1973, p. 75). The other two branches - the engineering and deck officers - were recruited from lower social classes but were anxious to secure higher social standing in a manner similar to what could be achieved by an executive officer. Executive officers were in charge of commanding a ship, but the technical skills that the other two branches held were absolutely vital for operating a modern warship. Hence the engineering and deck officers argued they were due a higher social standing. The executive officers were loath to grant this, fearing it would dilute their own standing (Herwig, 1973, p. 172, 173). The failure to resolve these conflicts during both peace and wartime resulted in an officer corps that was overall self-absorbed with its own desires for social advancement. Consequently, this compromised their performance. The engineering and deck officers, who normally acted as intermediaries between the sailors and the executive officers, began not to report cases of insubordination (Epkehnahns, 2005, p.72). The living conditions of the sailors became secondary concerns to questions of honour, ennoblement, and dignity. The sailors themselves were almost exclusively working class (Horn, 1969, p. 55). As such, officers saw 
themselves as naturally superior to the sailors. Overall, the attention paid to one's social standing within the officer corps indicates that class was of serious concern for officers. This attitude clearly carried over into their interactions with sailors, leading them also to think more in terms of class and the glaring inequalities therein - rather than national brotherhood, further weakening unity within the navy.

Richard Stumpf's diary is again illustrative of this. In a diary entry dated to August 15, 1915, he states that the entire crew of his SMS Helgoland is in agreement "that the privileges of the officers have to be abolished by the end of the war" (p. 119). This statement suggests that value of the nation as something that could overcome inequality no longer held, and the sailors no longer saw the nation as a sufficient justification for the war. Instead, some kind of political program to redress social inequality would be necessary to justify it. On the same page he adds "all of us wish that the Helgoland would run over a mine and the officer's quarters would be torn to pieces" (p. 119). Clearly, even this early in the war, there was significant ill will born by the sailors against the officers, and this was manifesting itself in the desire for social and political change. Later in his diary, on an entry dated March 18, 1918, Stumpf gives high praise to David Lloyd George: "If one believes the newspapers, he wishes to spend a billion marks to build homes for the soldiers. I simply must take off my hat to such a man" (p. 393). Thus, Stumpf was able to see the anemic pace of social reform in Germany contrasted with actual social change occurring in other countries, producing only further frustration. What makes Stumpf's attitude towards the war and the necessity for social reform all the more surprising is the fact that he was in general a staunch supporter of the monarchy. Traditionally, Chancellors had been appointed solely by the Kaiser. However, the appointment of Count Hertling to the position of Chancellor on October 30, 1917, was done in conjunction between the Kaiser and the Reichstag and many people took this to be a sign of impending parliamentary rule. In response to this Stumpf declared, "I am not at all pleased by the advent of the much heralded parliamentary system of government" (Stumpf, 1967, p.371), indicating his monarchical preferences. Thus, if Stumpf, as a monarchist, was frustrated, other less monarchist sailors could only have been more frustrated. The sanctity of the nation had been tarnished. A lack of action, boring and unfulfilling port life, poor rations, and a growing void between officers and sailors broke the sailors' morale and heightened their awareness of class identities and desire for social change. All that was needed now was a spark to set them off.

\section{The End of The War: The DeAth Ride of the german Navy AND the SAILORS' REVOLT}

The spark was provided when the navy's commanders decided to plan a suicide mission against the English fleet in order to maintain the prestige of the navy in the face of Germany's overall defeat. In 1918, the German army launched Operation Michael on the Western Front, a massive final attempt to secure victory in the war. While initially successful, it was soon turned back, and Germany's armies were in retreat (Merriman, 2010, p. 921). By September, the situation was dire. General Ludendorff, who had been in absolute command over the German armies, informed the Kaiser that an armistice was needed within 24 hours (Ryder, 1967, p. 122). This produced shock amongst all parts of the government, including the navy's commanders.

While the army was defeated and needed an armistice, the navy's commanders were determined to prove that the navy did not. This determination was borne out of the fact that the navy, and the surface fleet in particular, had done little during the war. In order to prove the navy's worth and therefore secure its future, as well as justifying the massive expense that had been lavished on the navy prior to the war, naval command began to plan for a climactic battle to the death against the Royal Navy (Herwig, 1973, p. 240-248). The navy had indeed cost an immense 
sum, adding over a billion marks to the German national debt between 1897 and 1914 (Herwig, 1980, p. 61). The fact that the navy's leadership was trying to secure the fleet's future through a suicide battle, which would inevitably result in the destruction of the fleet, illustrates that they had lost touch with reality. Nonetheless admirals Scheer, Trotha, von Levetzow, and Hipper, the men at this point largely in charge of the navy, went ahead planning the operation. During the planning, the admirals simply assumed that the sailors would obediently follow orders, reflecting the degree to which the officers were out of touch with the sailors. On October 29, 1918 the order was given for the entire High Seas Fleet to assemble at Wilhelmshaven ${ }^{1}$ (Epkehnahns, 2005, p. 79). Instead of obedience, the sailors responded with revolt.

Since the end of September, serious changes had occurred within Germany's government. In addition to telling the Kaiser that the army needed an armistice, General Ludendorff also indicated his impression that the allied powers would probably offer Germany a more lenient peace if they were negotiating with a parliamentary rather than monarchical government (Ryder, 1967, p.122). Accordingly, Prince Max von Baden, known for his liberal politics, was made the new Chancellor and was tasked with creating Germany's first parliamentary government and with negotiating peace with the allies. In what was a historic first, he also included the SPD in the government (Ryder, 1967, p. 123, 124). On October 26, new constitutional changes were signed into law which effectively made all branches of the military subordinate to the civilian government (Herwig, 1973, p. 248). None of the admirals recognized these changes and all the planning was done in secrecy; orders were given verbally not in the customary written manner. Neither the Kaiser nor Max von Baden was informed of the plan, making it technically illegal (Horn, 1969, p. 210). These changes provide a crucial context for the navy's planned suicide mission and the resulting naval revolt. Particularly, they made it clear that peace was imminent. The inclusion of the SPD in the new parliamentary government also suggested that there might be possibility for social reform. Seeing this, the sailors had no interest in throwing their lives away. The unconstitutional nature of the plan further undermined it. Over four years, the sailors had seen relatively little action, depriving them of experiences that could validate their service for the nation. Their sense of national identity and pride was further depredated by the miserable conditions and glaring inequalities they experienced between themselves and the officers. Now that the sailors' grievances were on the verge of being ameliorated, the admirals' far flung plan was the last straw that prompted revolt.

Once the order for the fleet to assemble at Wilhelmshaven was given, events proceeded rapidly. The sailors on numerous ships refused to sail or stoke the fires for the engines (Artelt, 2012, p. 19). Because the admirals' plan was technically illegal, they panicked and tried to meet the men halfway. The third battleship squadron was dispatched to Kiel, in the Baltic, as a means of indicating there was not going to be a final attempt to fight the English in the North Sea (Horn. p. $224,225)$. En route, though, some of the revolting sailors were arrested. In response, the sailors resolved to free their arrested comrades, and when the ships landed in Kiel they established a committee to organize their activities against the officers (Epkenhans, 2005, p. 80). Karl Artelt, one of the leaders of the sailors and a strong Social Democrat, declared: "This only fuelled our revolutionary commitment. We were determined to free the sailors" (Artelt, 2012, p. 19). Joining the sailors were workers from the naval yards in Kiel, who together established workers' and sailors' councils (Epkenhans, 2005, p. 80). Admiral Souchon, the military governor of Kiel, tried to quell the uprising with force, but the soldiers he sent refused to follow their orders (Epkenhans, 2005, p. 80). Artel, thinking in terms of class, stated "the infantrymen - like all of us simple workers and peasants, forced into a soldiers' uniform without any actual relation to the war joined our revolutionary movement" (Artelt, 2012, p. 22). However, the revolting sailors feared

${ }^{1}$ The German navy's main port on the North Sea 
that troops loyal to the government might still be brought to bear against them and thus some started to depart from Kiel, spreading the revolt to other cities (Epkenhans, 2005, p. 82). By November 6, Cuxhaven, Bremen, and Hamburg were all in the hands of workers' and soldiers' councils and other areas of the country were erupting in revolt and demonstrations (Ryder, 1967, p. 142-3). On November 9, Max von Baden resigned as Chancellor, naming SPD leader Freidrich Ebert as the new Chancellor. That same day Kaiser Wilhelm II abdicated and the following day, Ebert declared Germany a republic (Merriman, 2010, p. 957). Thus, the naval revolt played a key role in toppling the government of Imperial Germany.

Before concluding, a few points should be noted. The naval revolt and subsequent revolution did not result in the disintegration of German state that was created in 1871. As a whole, the regional differences that the navy was aimed at overcoming did not tear it apart. As such, the German national idea proved to have a certain degree of resilience. However, the capacity of this nation to overcome inequalities between different social circles was severely tested by the First World War, and amongst the sailors found to be lacking. Finally, the Imperial government, which was the state structure to which the German nation was subject, and a key part in the way it defined itself, was found to be inadequate in addressing these grievances. Thus, while the idea of a German nation survived the revolution, it had to undergo a serious reimagining.

\section{Conclusion}

Previous historiography has explained the relationship between German naval expansion and Germany's domestic sphere through the social imperialism thesis. This thesis argues that naval expansion was undertaken as a result of domestic considerations. While the thesis is correct in that there was a relationship between naval expansion and domestic factors, the relationship was not a causal one. The naval laws that authorized Germany's naval buildup were in response to foreign factors. Likewise, the worldview of Admiral Tirpitz, the man behind the growth of the navy, was focused on Germany's place in the world and ability to compete with other great powers, not on domestic issues. Rather, when the German empire began its process of naval expansion in 1897, the Imperial government saw the navy as a tool to build up Germany's national identity and tie together a young nation that still had strong regional differences. This article has sought to highlight and add to recent scholarship that has begun to investigate this phenomena. To this end, the practices of shipnaming conventions, ship launching ceremonies, and activities of the Flottenverein have been analyzed in terms of their nationalist contours. This article then went on to analyze the navy's role as a national symbol in the context of wartime. Indeed, the First World War put the national identity embodied in the navy to the test. The navy saw little action, creating a discrepancy between the 'greatness' of the nation it was supposed to represent and its actual ability to realize that greatness. Simultaneously, the poor quality of life for sailors serving in the navy, juxtaposed with superior and exclusive attitudes of their officers, began to call more attention to class rather than national identities; social reform began to overshadow notions of national greatness in the minds of sailors. The attempt of the officers to launch a suicide mission right when the war was about to end caused this situation to ignite. The ensuing revolt and then revolution resulted in a serious reevaluation of the German nation, one that was far different than the nation the navy had initially been constructed to represent. Therefore, within the German domestic sphere, the navy functioned as a focal point for the establishment of the German nation, and the continued negotiation of what the nation should be. 


\section{REFERENCES}

Anderson, B. (1983). Imagined communities: reflections on the origin and spread of nationalism. London: Verso.

Alexander, R. (2012). Europe's uncertain path, 1814-1914. Oxford: Wiley-Blackwell.

Alter, P. (1985). Nationalism. (S. McKinnon-Evans, Trans.). London: Edward Arnold.

Artelt, K. (2012). With the Red Flag to Vice-Admiral Souchon. (G. Kuhn, Trans.) All power to the councils! A documentary history of the german revolution of 1918-1919 (19-24). Oakland: PM Press.

Bönker, D. (2013). Global politics and Germany's destiny 'from an East Asian perspective:' Alfred von Tirpitz and the making of Wilhelmine navalism. Central European History 46, 61-96.

Berghahn, V. (1987). Modern Germany: Society, economy and politics in the twentieth century. Cambridge: Cambridge University Press.

Confino, A. (1997). The Nation as local metaphor: Württemberg, Imperial Germany, and national memory, 1871-1918. Chapel Hill: University of North Carolina Press.

Eley, G. (1976). Defining social imperialism: The use and abuse of an idea. Social History, 1, 265-290.

Epkenhans, M. (2004). William II and 'his' navy, 1988-1918. In A. Mombauer W. Deist (Eds.), The Kaiser: New Research on Wilhelm II's role in Imperial Germany (12-37). Cambridge: Cambridge University Press.

Epkenhans, M. (2005). 'Red Sailors' and the demise of the German empire, 1918. In C. M. Bell, \& B. A. Elleman (Eds.), Naval mutinies of the twentieth century: An international perspective.

Epkenhans, M. (2011). Dreadnought: A golden opportunity for Germany's naval aspirations. In A. Lambert, J. Rüger, \& R. Blyth (Eds.), The Dreadnought and the Edwardian Age.

Fairburn, B. (2008). Economic and social developments. In J. Retallack (Ed.), Imperial Germany, 1871-1918(18-39). Oxford: Oxford University Press.

Gordon C. A. (1964). The politics of the Prussian army, 1640-1945. New York: Oxford University Press.

Herwig, H. H. (1980). Luxury Fleet: The Imperial German Navy 1888-1918. London: George Allen \& Unwin Ltd.

Herwig, H. H. (1973). The German naval officer corps: A social and political history, 1890-1918. Oxford: Clarendon Press. 
Hewiston, M. (2008). Wilhelmine Germany. In J. Retallack (Ed.), Imperial Germany, 1871-1918 (18-39). Oxford: Oxford University Press.

Holmes, J. (2010). Mahan, 'A place in the sun,' and Germany's quest for sea power. Comparative strategy, 23, 37.

Horn, D. (1969). The German naval mutinies of World War One. New Brunswick: Rutgers University Press.

Lerman, K. A. (2008). Bismarckian Germany. In J. Retallack (Ed.), Imperial Germany, 1871-1918 (18-39). Oxford: Oxford University Press.

Loiperdinger, M. (2002). The beginning of german film propaganda: The navy league as travelling exhibitor, 1901-1917. Historical journal of film, radio, and television, 22, 305-313.

Massie, R. K. (1991). Dreadnought: Britain, Germany, and the coming of the Great War. New York: Random House.

Merriman, J. (2010). A history of modern Europe: From the Renaissance to the present. London: W. W. Norton \& Company.

Mommsen, W. J. (1990). Imperial Germany, 1867-1918: Politics, culture and society in an authoritarian state. New York: St. Martin's Press Inc.

Park. E. (2015). The nationalist fleet: Radical nationalism and the Imperial German navy from unification to 1914. Journal of Military and Strategic Studies, 16, 125-159.

Rüger, J. (2007). The great naval game: Britain and Germany in the age of empire. Cambridge: Cambridge University Press.

Ryder, A. J. (1967). The German revolution of 1918: A study of german socialism in war and revolt. Cambridge: Cambridge University Press.

Stumpf, R. (1967). War, mutiny, and revolution in the German navy: The World War One diary of seaman Richard Stumpf. (D. Horn, Trans.) New Brunswick: Rutgers University Press.

Thomas, K. A. (1991). Wilhelm II and the Germans: A study in leadership. London: Oxford University Press. 